\title{
Service Innovation Capability and Innovation Performance in Distribution Store: A Conceptual Framework
}

\author{
Evo Sampetua Hariandja \\ Business School, Department of Management \\ Universitas Pelita Harapan \\ Tangerang, Indonesia \\ evo.hariandja@uph.edu
}

\begin{abstract}
Distribution store and clothing industry in Indonesia has demonstrated critical development and addition more noteworthy consideration in today's business surroundings especially in creative industries. The development of creative industry gives contribution for Indonesia economic. That thing happen because the creativity of the youth society and their courageous in experimenting with innovative ideas. The research aims to study the phenomenon of synergy between service innovation capability and innovation performance in the context of Indonesian distribution store and clothing industry. The aftereffects of this study can be utilized to further support the creative business. The study seeks to develop a model that link two main variables: service innovation capability and innovation performance. This link has been given little attention by prior research particularly in the creative industry. The proposed model is discussed in the paper.
\end{abstract}

Keywords-creative industry, distribution store/clothing, organizational competencies, service innovation capability, innovation performance

\section{INTRODUCTION}

Various countries at this time began to realize the economic potential can be resulting from the creativity of its people. Creativity society has become part of the culture and shaping extravagance for every country. The forms of creativity are embodied in multitudinous craft products, clothing, dance, and performance art, films, animation, comics, and others. Embodiment shape people's creativity can be grouped in an industry sector that is known to the industry sector creative. Home to the fine art of batik, fluctuating musical and execution styles; Indonesia's rich social differing qualities and legacy give ripe ground to a flourishing creative industry. Long time cabin commercial ventures of craftsmanship and artworks have the degree to end up universally looked for after products, outlined by the sudden development in Indonesia's contemporary workmanship market. Such innovativeness is reaching out into different commercial ventures, for example, promoting, style, music generation and distributed contributing a sum of $7.2 \%$ of GDP and $9 \%$ of fare quality in 2010 . The capability of the creative industry is a center need of the legislature through the Ministry of Trade, with the objective of $8 \%$ of GDP for 2011 and also expanding absolute fare worth to $12 \%$ by 2015 .

The creative industry is exceedingly different split extensively more than 14 industry classes including publicizing, style, outline, music and programming improvement. Style remains the overwhelming subsector of the creative industry in Indonesia regarding commitment to GDP at $63.3 \%$ for 2010 took after by specialties at $33.2 \%$. The division is comprised of a large number of SMEs at an expected $6.74 \%$ of aggregate organizations in Indonesia and is a noteworthy wellspring of new entrepreneurism among the nation's childhood. Commitment to sends out expanded by more than $35 \%$ from 2006 to 2010 (Ministry of Trade) which is noteworthy considering its relative oddity as a business subsector.

The legislature has been eminently dynamic in advancing Indonesia's creative abilities and fare potential. Under the Ministry of Trade, 2009 was assigned as the 'Year of the Creative Industry' with the association of displays all through the nation and abroad to showcase neighborhood organizations and items. Such eagerness was likewise reflected in solid activity under Presidential Instruction No. 6/2009 requiring 24 legislative bodies to plan programs for building up the segment. For 2011, the pattern proceeds with 50 billion RP apportioned by the Ministry of Trade for advancement and abroad abilities preparing. State possessed banks are additionally being coordinated to loan more to business people in the creative fields. The future improvement of 'creative urban areas' that would make groups in particular creative subdivisions is a further move by the service to build up Indonesia's human asset potential. Such urban areas are being made close by the British Arts Council and are normal by 2014 as a feature of the Creative Economy Blueprint and will be discovered at first in Bandung, Semarang, Yogyakarta and Bali. They will assume a key part in encouraging the move from being center points for overwhelming industry to that of information based economies of scale.

Indonesia's creative commercial enterprises hold extraordinary potential and government activities are building solid establishments for the area. Prompt qualities lie in customary ranges of creation, for example, batik which is reflected in the design industry and also furniture, for example, rattan and teak. However, the ascent of the advanced age in zones, for example, publicizing, music and programming is seeing a continuous movement in the predominance of subsegments inside the industry. The coming years will see more noteworthy personalization in the advanced business sector to meet buyer and also business needs as web entrance increments quickly. The following strides will be to make the creative 
industry feasible and will require a generous movement with respect to the administration in licensed innovation rights to secure its business people.

\section{LITERATURE REVIEW}

\section{A. Resources and Capabilities}

In (1) states that resources as a strength or weakness of a given firm. According to (2), define resources as "...firmspecific assets that are difficult if not impossible to imitate and transfer that may contain tacit knowledge". In (3) who reproduce (4) define and describe firm resources as "all assets, capabilities, organizational processes, firm attributes, information, knowledge, etc. controlled by a firm that enable the firm to conceive of and implement strategies that improve its efficiency and effectiveness". According to (5), resources are the source of a firm's capabilities, and capabilities are the main source of its competitive advantage. Resources also viewed as stocks of available factors that are owned or controlled by the firm and capabilities as a firm's capacity to deploy resources, usually in combination, using organizational processes, to effect a desired end that based on developing, carrying and exchanging information through the firm's human capital (6). Along these lines, resources are the input mechanism when to accomplish maintained competitive advantage and the capabilities may be required in doing so.

In (7) point out that each firm has a long rundown of assets and as per the RBV are not all assets of the same investment or can possibly be a wellspring of sustainable competitive advantage. The writing concerning the resource based perspective has centered to an expansive degree on the attributes of these purported strategic resources. According to (7), review diverse attributes of resources to be wellsprings of competitive advantage.

Given the presumptions that firm resources are heterogeneous and not impeccably portable, the structure of (3) expresses that a firm resource may achieve sustained competitive advantage if four particular properties concerning the resources are satisfied. These four characteristics concerning the firm resources are as tails: (I) it must be valuable, (II) it must be rare, (III) it additionally must be defectively imitable, and (IV) no deliberately identical substitutes for the asset that are profitable however not uncommon or incompletely imitable. Barney remarks these characteristics and express that it is not tricky to see that important and uncommon firm resources may be a wellspring of competitive advantage, however these resources must be wellsprings of sustained competitive advantage if different firms can't attain them, then these resources are incompletely imitable. Firm resources might be defectively imitable as a result of one or a synthesis of three clarifications: (I) the accomplishment of an resource is subject to one of a kind chronicled conditions, (II) the relationship between the firm resources and sustainable competitive advantage is causally uncertain, or (III) the resource is socially perplexing (3).

\section{B. Service Innovation Capability}

Service sector has ruled the world's economy. In many nations, benefits these days help more financial qualities than horticulture, raw materials and manufacturing all together. Service economies' overwhelming position is clearer in developed countries. Up to seventy-five percent of the riches and $85 \%$ of work are created by services (8), and newest occupation development originates from services.

The importance of service has been perceived by enterprises, institutes, and governments, and related research is progressing. Inside different angles and orders of Service Science, service innovation along these lines turns into one focal part because of its basic part. Since Goods-Dominant Logic has been standard rationale for quite a while, the extent that innovation is concerned, the experience from manufacturing will be reminded to most corporations and customers firstly. On the other hand, there are fundamental qualifications between service innovation and manufacturing or high-tech innovation. With the movement from GoodsDominant Logic to Service-Dominant Logic, the innovation concept and process require likewise move from conventional viewpoint to another services point of view.

As recommended by (9), "service is a perspective on value creation rather than a category of market offerings. The focus is on value through the lens of the customer, and co-creation of value with customers is key and the interactive, processual, experiential, and relational nature form the basis for characterizing service". Thus, client focused and processual thought can likewise be seen in one of the meanings from TEKES, a Finland's research Agency. "Service innovation is a new or significantly improved service concept that is taken into practice". It could be for instance another client collaboration channel, a dissemination framework or an innovative idea or a combo of them. A service innovation dependably incorporates replicable components that might be recognized and efficiently recreated in different cases or situations. The replicable component could be the services result or the services handle in that capacity or a piece of them. A service innovation benefits both the service producer and customers and it enhances its developer's competitive edge.

For service innovation dynamic capability, this study adopted from (10), that contains sensing, seizing, and transforming (2). Sensing refers to the distinguishing proof of the need to change service operations or opportunities for service innovation, seizing alludes to investigating and selecting plausible open doors for change, and transforming is concerned with the execution of changed (or new) benefits in the organization. Adjust to this observation, the models of new service development, service engineering, service innovation, or services design might be seen as particular portrayals of the element ability service innovation.

Sensing refers to the services of distinctive knowledge and learning that need to be deciphered into heading issues and unmet services needs before a more centered conceptualization of new services results follows in the seizing stage (11). Sensing principally incorporate three key 
exercises: 1) checking, 2) assessment, and 3) enumerating. Examining may require the consistent dialog with clients, faculty, and innovation suppliers. Assessing alludes to the capacity of an organization to immediately screen a specific open door or requirement for administration development as to, for example, the issue circumstance overall (12), business targets (13), (14) or general attainability (15). The enumerating movement alludes to decisively characterizing the issue and explaining side conditions (e.g., innovation, enactment and social angles) that need to be considered inside the advancement of conceivable results, e.g., by method for new service process (16) or administration ideas (17).

Seizing: Seizing recognize three principle exercises: 1) result improvement, 2) result assessment and determination, and 3 ) result enumerating. The result improvement alludes to the action of administration association's capability to produce distinctive potential results and therefore to distinguish conceivable ways it could take in upgrading their administration offerings as indicated by the long ago defined issue, for example, administration methodology plan, idea advancement, issue determination, building option results, or thought refinement. The improvement of new results additionally comprises in inventively modifying existing administrations into creative bundles. The movement of result assessment and determination that take into account educated choice making and hence for selecting the most sufficient answer for a particular issue. The result specifying capability includes the last determination of the to-be procedures, strategies, offices, data frameworks, members, and practices that need to be placed set up for the new service. Here, the improvement of an extensive undertaking arrangement for the execution of the chose result needs to be advanced and usage venture groups and in addition control components must be set up.

Transformation: Transformation isolated into three exercises of unfreezing, changing, and refreezing (18). Unfreezing alludes to separating existing work structures which is a vital viewpoint when executing new service methods and interfaces to the client. The changing action alludes to the genuine execution of the new service. At last, the solidifying action identifies with all errands important to cultivate disguise of the recently executed service process, for example, persistent inspiration (19) and trainings (20). Moreover, the utilization of data frameworks (in light of the fact that product meets expectations in a characterized manner) and the utilization of correspondence and advancement devices (through which clients embrace institutionalized desires) can help solidifying another administration. The objective of this movement is to attain a routinization; this implies that the staff receives the new service offering and changes the unequivocal information about what the new service is similar to and how to convey it into inferred learning (21).

\section{Innovation Performance}

Of late, innovation has turned out to be progressively noticeable in studies on firm performance. Better innovation gives firms opportunities than develop speedier, preferred and more brilliant over their rivals (22), (23), (24). Since innovation regularly includes more prominent monetary venture and R\&D limit, numerous organizations team up and impart assets to various sorts of accomplices to enhance their association's rate and nature of innovations (25). Hence utilizing innovation as a measure of performance gives off an impression of being a huge commitment to concentrates on distribution store and clothing industry. As far as builds, exploration has for the most part characterized innovation as curiosities or enhancements in different measurements of business (26) especially item, benefit, market, process, supply and general organization. A few studies have utilized more particular measures of innovation, for example, pace of prologue to the commercial center (27) or number of licenses (28). In exploratory research, be that as it may, researchers ordinarily look at a blend of innovations, for example, enhancements in item quality, use of new advancements and crude materials, improvement of new market fragments, organizational rebuilding, and so forth. In (29), component investigation has created 20 things measuring different sorts of innovation which are in accordance with the reason for the present study. These measures of innovation incorporate items, administrations and business sector advancement, and new procedures and administration approaches.

\section{Service Innovation and Performance}

Innovativeness is an imperative determinant of an organization's performance (30), (31). Along these lines, organizational performance can be enhanced through technical and administrative innovation other than different elements (32). Past exploration has examined the impacts of innovations furthermore, innovativeness on organizational performance (30), (33), (34), (35), (36), (37), (38). Improving firms have been found to have more elevated amounts of productivity and monetary development than non-advancing firms (33). Technical innovations as well as organizational innovations are vital conditions for enhancing performance and for expanding the company's value (32), (35). Organizational innovations not just set up a reasonable milieu for the other innovation sorts, additionally have a solid and direct effect on creative performance (37). What's more, a company's general performance and organizational innovations are entirely and decidedly related to each other (39). In this manner, administrators ought to perceive and deal with the innovations keeping in mind the end goal to help their operational performance (37).

\section{CONCEPTUAL MODEL}

The conceptual framework consists of the linking of the factors involved in the research and constituted the conceptual model on how a theory or logical sense of a relationship is identified to the problem. The literature review which is explained in the previous performs the conceptual framework of this study as displayed in Figure 1. This research will explore and examines the relationship between the variables of 
service innovation capability and innovation performance in the context of distribution store and clothing industry.

\begin{tabular}{|l|l|}
\hline $\begin{array}{c}\text { Service Innovation } \\
\text { Capability }\end{array}$ \\
\hline - Sensing \\
- Seizing
\end{tabular}$\quad \rightarrow$\begin{tabular}{l}
$\begin{array}{l}\text { Innovation Performance: } \\
\text { Transforming } \\
\text { - R N intensity } \\
\text { - The share of } \\
\text { turnover due to new } \\
\text { products \& process }\end{array}$ \\
\hline
\end{tabular}

Figure 1. Conceptual Model

The main focus of the conceptual model would be in integrating component of service innovation capability and innovation performance in the distribution and clothing industry, and exploring the intensity of service innovation and influence on innovation performance. The type of service innovation is being conducted in the companies included product, process, market, organizational, customization, and usage of IT. Product-related factors: product advantage, technical quality, functional quality and innovative technology.

\section{CONCLUSIONS}

This study has proposed a model of service innovation capability in relation to the innovation performance in the distribution store and clothing industry. It has found this relationship to be further unveiled due to the intense innovation and the complexity of processes involved in the distribution and clothing industry. The findings of the model are significant to the research and the distribution and clothing industry for their business improvement especially in becoming more responsive to their customers.

\section{REFERENCES}

[1] Wernerfelt B. A resource-based view of the firm. Strategic management journal. 1984;5(2):171-80.

[2] Teece DJ, Pisano G, Shuen A. Dynamic capabilities and strategic management. Strategic management journal. 1997:509-33.

[3] Barney J. Firm resources and sustained competitive advantage. Journal of management. 1991;17(1):99-120.

[4] Daft RL. Learning the craft of organizational research. Academy of Management Review. 1983;8(4):539-46.

[5] Grant RM. The resource-based theory of competitive advantage: implications for strategy formulation. California management review. 1991;33(3):114-35.

[6] Amit R, Schoemaker PJ. Strategic assets and organizational rent. Strategic management journal. 1993;14(1):33-46.

[7] Fahy J. The resource-based view of the firm: some stumbling-blocks on the road to understanding sustainable competitive advantage. Journal of European industrial training. 2000;24(2/3/4):94-104.

[8] Tidd J, Hull F. Service innovation. Organizational Responses to. 2003.

[9] Edvardsson B. Service quality: beyond cognitive assessment. Managing Service Quality: An International Journal. 2005;15(2):127-31.

[10] Pöppelbuß J, Plattfaut R, Ortbach K, Malsbender A, Voigt M, Niehaves $\mathrm{B}$, et al., editors. Service innovation capability: Proposing a new framework. Computer Science and Information Systems (FedCSIS), 2011 Federated Conference on; 2011: IEEE.

[11] Hertog Pd. Managing service innovation: firm-level dynamic capabilities and policy options: Dialogic Innovatie \& Interactie; 2010.
[12] Chai K-H, Zhang J, Tan K-C. A TRIZ-based method for new service design. Journal of Service Research. 2005;8(1):48-66.

[13] Bitran G, Pedrosa L. A structured product development perspective for service operations. European Management Journal. 1998;16(2):169-89.

[14] Bernstein B, Singh PJ. An integrated innovation process model based on practices of Australian biotechnology firms. Technovation. 2006;26(5):561-72.

[15] Majaro S. The creative gap: Managing ideas for profit: Longman Trade/Caroline House; 1988.

[16] Basadur M, Pringle P, Speranzini G, Bacot M. Collaborative problem solving through creativity in problem definition: Expanding the pie. Creativity and Innovation Management. 2000;9(1):54-76.

[17] Goldstein SM, Johnston R, Duffy J, Rao J. The service concept: the missing link in service design research? Journal of Operations management. 2002;20(2):121-34.

[18] Cartwright D. Achieving Change in People: Some Applications of Group Dynamics Theory1. Group Facilitation. 2008(9):59.

[19] Mento A, Jones R, Dirndorfer W. A change management process: Grounded in both theory and practice. Journal of Change Management. 2002;3(1):45-59.

[20] Scheuing EE, Johnson EM. A proposed model for new service development. Journal of Services marketing. 1989;3(2):25-34.

[21] Stevens E, Dimitriadis S. Managing the new service development process: towards a systemic model. European Journal of Marketing. 2005;39(1/2):175-98.

[22] Freitas IMB. Sources of differences in the pattern of adoption of organizational and managerial innovations from early to late 1990s, in the UK. Research Policy. 2008;37(1):131-48.

[23] Prajogo DI, Power DJ, Sohal AS. The role of trading partner relationships in determining innovation performance: an empirical examination. European Journal of Innovation Management. 2004;7(3):178-86.

[24] Bontis N, Bart C, Sáenz J, Aramburu N, Rivera O. Knowledge sharing and innovation performance: A comparison between high-tech and lowtech companies. Journal of Intellectual Capital. 2009;10(1):22-36.

[25] Tsai K-H, Hsieh M-H. How different types of partners influence innovative product sales: Does technological capacity matter? Journal of Business Research. 2009;62(12):1321-8.

[26] Johannessen J-A, Olsen B, Lumpkin GT. Innovation as newness: what is new, how new, and new to whom? European Journal of innovation management. 2001;4(1):20-31.

[27] Kessler EH, Allocca MA, Rahman N. External knowledge accession and innovation speed in the small and medium sized enterprise (SME). Small Enterprise Research. 2007;15(1):1-21.

[28] Shane S. Cultural influences on national rates of innovation. Journal of Business Venturing. 1993;8(1):59-73.

[29] Wang CL, Ahmed PK. The development and validation of the organisational innovativeness construct using confirmatory factor analysis. European journal of innovation management. 2004;7(4):30313.

[30] Calantone RJ, Cavusgil ST, Zhao Y. Learning orientation, firm innovation capability, and firm performance. Industrial marketing management. 2002;31(6):515-24.

[31] Hult GTM, Hurley RF, Knight GA. Innovativeness: Its antecedents and impact on business performance. Industrial marketing management. 2004;33(5):429-38.

[32] Montes FJL, Moreno AR, Morales VG. Influence of support leadership and teamwork cohesion on organizational learning, innovation and performance: an empirical examination. Technovation. 2005;25(10):1159-72.

[33] Cainelli G, Evangelista R, Savona M. The impact of innovation on economic performance in services. The Service Industries Journal. 2004;24(1):116-30.

[34] 34. Keskin H. Market orientation, learning orientation, and innovation capabilities in SMEs: An extended model. European Journal of innovation management. 2006;9(4):396-417. 
[35] Bowen FE, Rostami M, Steel P. Timing is everything: A meta-analysis of the relationships between organizational performance and innovation. Journal of Business Research. 2010;63(11):1179-85.

[36] Rhee J, Park T, Lee DH. Drivers of innovativeness and performance for innovative SMEs in South Korea: Mediation of learning orientation. Technovation. 2010;30(1):65-75.
[37] Gunday G, Ulusoy G, Kilic K, Alpkan L. Effects of innovation types on firm performance. International Journal of production economics. 2011;133(2):662-76.

[38] Jiménez-Jiménez D, Sanz-Valle R. Innovation, organizational learning, and performance. Journal of business research. 2011;64(4):408-17.

[39] Mazzanti M, Pini P, Tortia E. Organizational innovations, human resources and firm performance: The Emilia-Romagna food sector. The Journal of Socio-Economics. 2006;35(1):123-41. 